Penentuan Jenis ... (Amin Fathoni, dkk)

\title{
PENENTUAN JENIS DAN KONSENTRASI PELARUT UNTUK ISOLASI ZAT WARNA KULIT BUAH MANGGIS (GARCINIA MANGOSTANA L)
}

\author{
Amin Fatoni, Mando Hastuti, Dwi Agustina V, Suwandri \\ Program Studi Kimia MIPA Fakultas Sains dan Teknik UNSOED Purwokerto
}

\begin{abstract}
Natural pigment recently have interest to explore to reduce synthetic chemical effect for organism and environment. Mangostine (Garcinia mangostana L) is one of tropical fruit that have peel strong pigment, thus potent as new natural pigmen. Solvents including water, ethanol and methanol applied to extract mangostine peel pigment. The best solvent determined by measuring pigment filtrate using spectrophotometer. The highest absorbance data indicated the best solvent, i.e. more extract yielded by this solvent. The optimum concentration of the solvent for best extraction also investigated with the same procedure above, and finally the natural pigment obtained identified using paper chromatography. The best solvent investigated for extraction was ethanol at concentration $70 \%$. The pigment extracted from mangostine peel proposed as pellargonidine 3-glycoside group of anthocyanin
\end{abstract}

Keywords : natural pigment, mangoostine peel, pigment extraction.

\section{PENDAHULUAN}

Manggis (Garcinia mangostana L) merupakan salah satu tanaman buah asli dari Indonesia yang mudah tumbuh di daerah tropis. Buah ini banyak digemari baik dalam maupun luar negeri karena rasanya yang manis, segar dan berair serta mempunyai kandungan dan komposisi gizi yang sangat dibutuhkan oleh tubuh. Di antara buah-buahan tropis lainnya yang umumnya berasa sangat manis dan beraroma tajam, manggis dianggap sebagai buah yang paling enak dari daerah tropis. Oleh karena itu, manggis dikukuhkan sebagai the queen of tropical fruits "Ratu Buah-Buahan dari Khatulistiwa" (Reza, dkk, 1994, Rismunandar, 1986, dan Rukmana, 1995).

Produksi manggis di Indonesia dari tahun ke tahun terus meningkat, bahkan buah ini juga laku di pasaran luar negeri (ekspor). Produk utama dari manggis adalah buahnya yang dapat dikonsumsi sebagai buah segar maupun diproduksi sebagai minuman segar.
Produk sampingnya berupa kulit buahnya. Kulit buah manggis berukuran tebal mencapai proporsi sepertiga bagian dari buahnya (Rukmana, 1995).

Dirjen Tanaman Pangan dan Hortikultura (2004), menjelaskan bahwa kulit manggis merupakan komoditi ekspor. Secara visual kulit buah manggis mempunyai warna yang tajam. Kulit manggis secara visual berwarna merah lembayung. Harborne (1996) menjelaskan bahwa zat warna alami yang berwarna merah lembayung merupakan senyawa sianidin yang termasuk golongan antosianin. Penelitian tentang pigmen kulit buah manggis sebagai pewarna alami sampai saat ini belum dilakukan, untuk itu maka pada penelitian ini akan dicobakan mengekstraksi pigmen antosianin dari kulit buah manggis dengan tujuan dapat dimanfaatkan sebagai pewarna alami.

Zat warna alami menarik untuk diteliti karena dampaknya yang lebih kecil baik terhadap organisme maupun 
lingkungan dibandingkan dengan zat warna sintetik. Pada penelitian terdahulu telah dilakukan penelitian zat warna dari buah yang memiliki famili sama dengan buah rambutan yaitu ekstraksi pigmen antosianin dari kulit buah lyche (Lee dan Wicker, 1991). Untuk itu diasumsikan bahwa zat warna kulit buah manggis dapat diisolasi untuk selanjutnya dapat digunakan sebagai pewarna alami, seperti penelitian yang dilakukan Wijaya, dkk (2001) yang mengekstraksi zat warna alami kulit buah rambutan.

Penelitian mengenai isolasi zat warna kulit buah manggis sejauh ini belum ditemukan, sehingga perlu dilakukan. Pada penelitian ini, zat warna dari kulit buah manggis akan diekstraksi menggunakan berbagai pelarut dengan variasi konsentrasi, sehingga dapat diketahui pelarut yang terbaik untuk ekstraksinya.

\section{METODOLOGI PENELITIAN Alat dan Bahan}

Bahan yang digunakan antara lain : kulit buah manggis, metanol, etanol, $\mathrm{HCl}$, akuades, buffer asam sitrat, hidrogen peroksida, asam askorbat, butanol, dan asam asetat glasial.

Peralatan yang digunakan dalam penelitian ini antara lain : peralatan gelas laboratorium, spektrofotometer UV-Vis, kertas Whatman 42, kertas kromatografi, penguap putar, penyaring vakum, sentrifuge, pemanas, lampu TL $20 \mathrm{~W}$, corong pisah, termometer, dan $\mathrm{PH}-$ meter.

\section{Prosedur Percobaan \\ Pengumpulan contoh}

Contoh kulit buah manggis diperoleh dari buah manggis di pasar tradisional Purwokerto. Contoh kulit buah manggis yang diperoleh dari berat buah segar sekitar $5 \mathrm{~kg}$. Contoh sebelum dianalisis disimpan dalam suhu dingin (2 $8^{\circ} \mathrm{C}$ ) dan terlindung dari cahaya untuk menghindari kerusakan awal zat warna.

\section{Penentuan jenis pelarut}

Kulit buah manggis segar dipotong kecil-kecil (1-2 cm), kemudian dihaluskan dengan blender selama 5 menit. Kulit buah manggis halus sebanyak 20 g diekstraksi dengan pelarut sebanyak $100 \mathrm{~mL}$, dengan pengadukan selama 30 menit. Pelarut yang dicoba dalam penelitian ini antara lain : metanol (mengandung $\mathrm{HCl} \mathrm{1 \% ),}$ etanol-HCl (85:15), dan air. Proses ekstraksi dikondisikan agar contoh terlindung dari cahaya.

Campuran contoh-pelarut selanjutnya disentrifuge pada kecepatan $6000 \mathrm{rpm}$ selama 5 menit, dan kemudian disaring menggunakan kertas Whatman 42 dengan bantuan pompa vakum. Filtrat yang diperoleh diukur intensitas warnanya menggunakan spektrofotometer.

\section{Penentuan konsentrasi pelarut}

Percobaan dilakukan dengan cara yang sama seperti pada penentuan jenis pelarut, dengan perbedaan pada konsentrasinya. Setelah diketahui jenis pelarut terbaik dalam percobaan awal, kemudian pelarut tersebut divariasikan konsentrasinya $(50,60,70,80$, dan 95\%) untuk mendapatkan konsentrasi yang paling optimum dalam ekstraksi ini.

\section{Identifikasi jenis zat warna}

Filtrat zat warna terbaik yang diperoleh (dari jenis maupun konsentrasi pelarut terbaik) dilakukan identifikasi jenis zat warnanya menggunakan kromatografi kertas dengan larutan pengembang BAA (butanol-asam asetat-air), $\mathrm{BuHCl}$ (butanol-HCl), dan $\mathrm{HCl} 1 \%$. Jenis pelarut dibandingkan dengan nilai $\mathrm{Rf}$ standar zat warna alami (Harborne, 1987).

\section{Analisis Data}

Penentuan jenis pelarut dan konsentrasi pelarut terbaik dianalisis 
varian (ANOVA) menggunakan bantuan konsentrasi pelarut. Tingkat kepercayaan yang digunakan dalam analisis ini adalah 95\%. Jika keragamannya nyata, maka dilakukan uji BNJ (Beda Nyata Jujur / Tukey) untuk mengetahui tingkat perbedaan antar perlakuan.

\section{HASIL DAN PEMBAHASAN}

\section{Penentuan Jenis Pelarut}

Pelarut untuk ekstraksi zat warna kulit buah manggis dipilih dari beberapa pelarut yaitu etanol, metanol dan air. Pemilihan etanol sebagai pelarut didukung oleh banyak literatur (Bao dan Chang, 1994, Rahayu 1989, Lee and Wicker 1991, Budiarto 1991, Jenie, dkk 1994, Shi, dkk, 1992, Williams dan Hrazdina, 1979, dan Hanum 2000) yang menyebutkan bahwa antosianin adalah pigmen yang sifatnya polar dan akan larut dengan baik dengan pelarut-pelarut polar. Metanol dipilih sebagai pelarut karena antosianin bersifat polar, sehingga pelarut ini umumnya digunakan untuk esktraksi antosianin (Harborne, 1996). Harborne juga menyebutkan bahwa antosianin merupakan pigmen berwarna kuat dan larut dalam air.

Filtrat zat warna kulit manggis ketiga pelarut yang diperoleh diukur program SPSS 15, dengan faktor jenis / menggunakan spektrofotometer visibel untuk mengetahui perbedaan intensitas absorbansinya. Hasil pengamatan absorbansi ekstrak ketiga pelarut tersebut terlihat pada Gambar 1.

Panjang gelombang maksimum untuk zat pewarna kulit buah manggis tercapai pada nilai $520 \mathrm{~nm}$, secara visual zat pewarna yang diperoleh berwarna merah. Harborne (1996) menyebutkan bahwa zat warna yang dideteksi dengan sinar tampak berwarna jingga, merah atau merah senduduk adalah antosianidin 3glikosida. Berdasarkan ciri spektrumnya, zat warna dengan panjang gelombang maksimum 475 - 560nm adalah antosianin. Hal ini mengindikasikan bahwa zat warna yang diperoleh dari ekstraksi kulit buah manggis diduga merupakan golongan antosianin. Masih perlu dilakukan identifikasi lebih lanjut untuk meyakinkan dugaan ini.

Gambar 1 menunjukkan bahwa pada panjang gelombang $520 \mathrm{~nm}$, nilai absorbansi tertinggi ditunjukkan oleh absorbansi dari ekstrak pewarna yang menggunakan pelarut etanol dan berbeda nyata $(\mathrm{p}: 0,05)$ dengan absorbansi zat warna dengan pelarut lain.

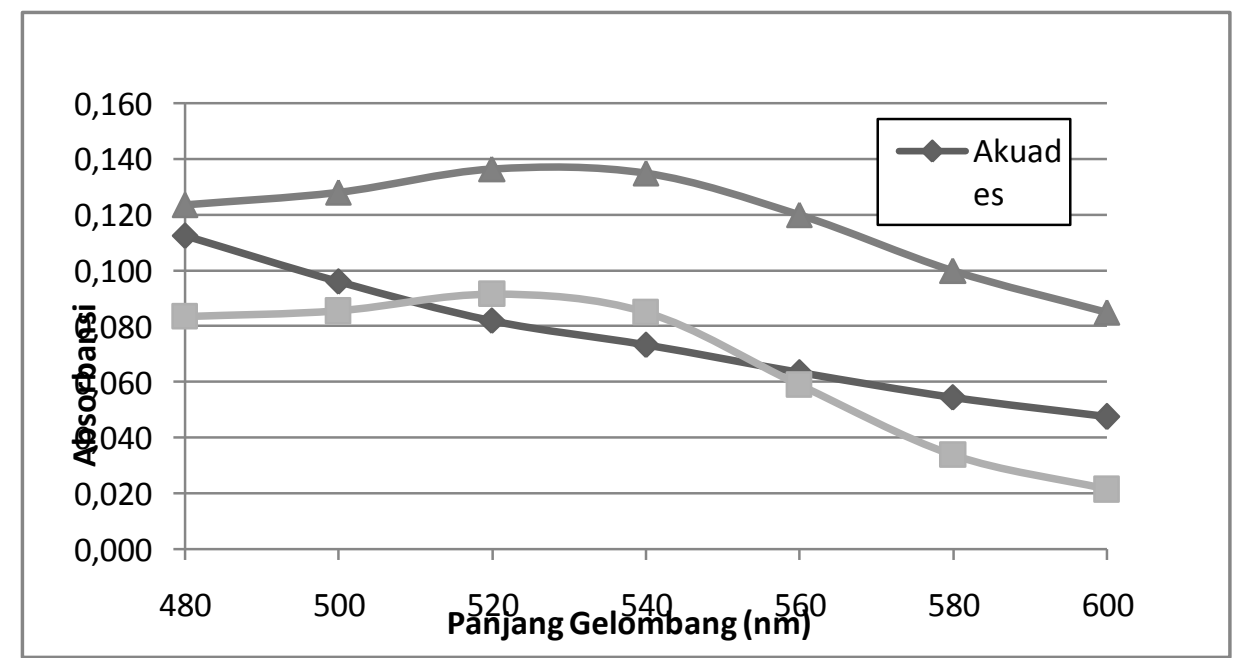

Gambar 1. Grafik nilai absorbansi ekstrak kulit buah manggis pada berbagai pelarut 


\section{Penentuan Konsentrasi Pelarut}

Setelah diketahui pelarut yang terbaik untuk ekstraksi zat pewarna kulit buah manggis ini, tahap selanjutnya adalah pemilihan konsentrasi etanol yang paling baik untuk ekstraksi. Konsentrasi yang di cobakan pada penelitian ini adalah $50 \%, 60 \%, 70 \%, 80 \%$ dan $95 \%$, dengan cara ekstraksi yang sama dengan pemilihan pelarut. Hasil pengamatan pemilihan konsentrasi etanol seperti terlihat dalam Gambar 2. Grafik tersebut menunjukkan bahwa nilai absorbansi tertinggi pada panjang gelombang berkisar antara $500-560 \mathrm{~nm}$ ditunjukkan oleh etanol dengan konsentrasi $70 \%$.

Nilai absorbansi zat warna kulit manggis dengan etanol 70\% menunjukkan perbedaan nyata $(\mathrm{p}: 0,05)$ dengan konsentrasi lain yang diujikan, sedangkan untuk konsentrasi yang lebih tinggi ( $80 \%$ dan 90\%) ternyata tidak berbeda nyata dengan konsentrasi etanol
$50 \%$ - 60\%, sehingga etanol dengan konsentrasi $70 \%$ paling optimal dapat megekstraksi zat warna kulit buah manggis.

Zat warna kulit manggis terekstrak baik dengan etanol $70 \%$, yang dapat diakibatkan oleh sifat antosianin yang kurang polar. Harborne (1996) menyebutkan bahwa flavonoid berupa senyawa yang larut di dalam air dan dapat diekstraksi dengan etanol $70 \%$. Hasil tersebut dapat menimbulkan dugaan bahwa etanol dengan konsentrasi $70 \%$ mempunyai kepolaran yang sama dengan zat warna yang terdapat pada kulit buah manggis. Naimah dan Lina (2004) menyatakan bahwa antosianin larut baik dalam alkohol, disebabkan karena alkohol mempunyai kepolaran yang sama sehingga mampu melarutkan antosianin.

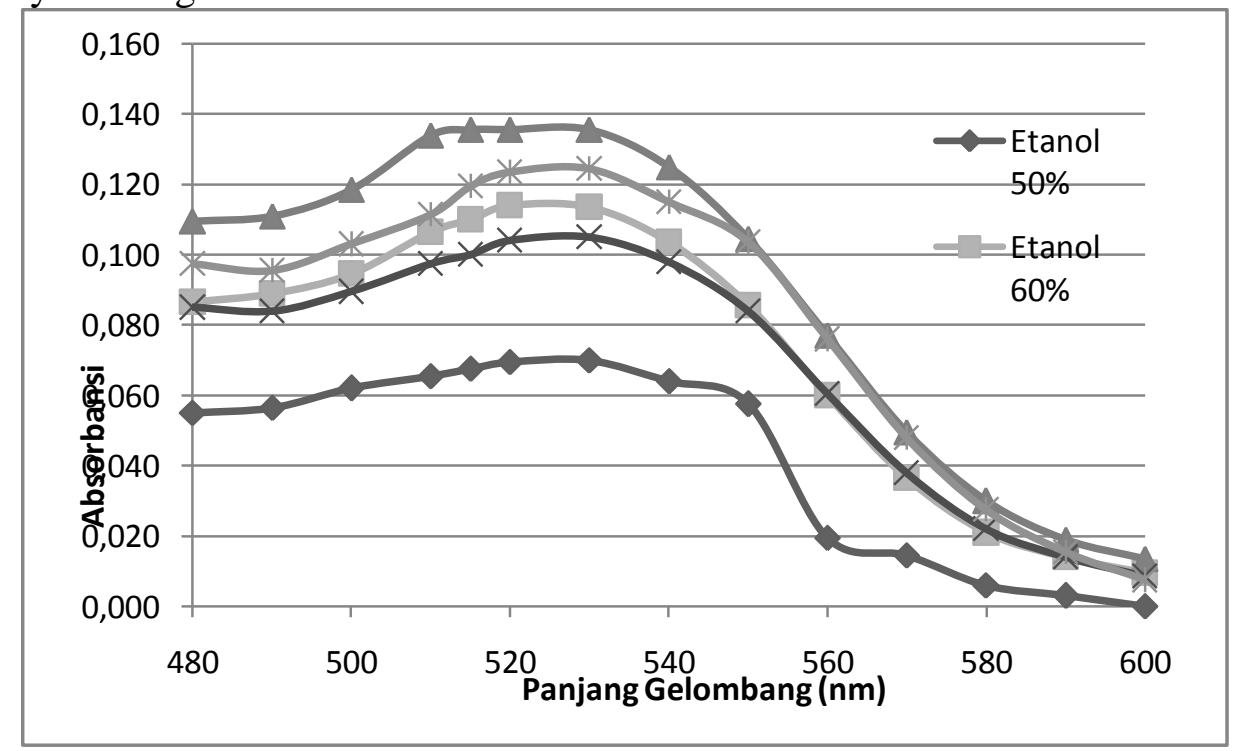

Gambar 2. Grafik absorbansi ekstrak kulit buah manggis dengan etanol pada berbagai konsentrasi

\section{Identifikasi Golongan Zat Warna}

Penelitian tahap ini adalah identifikasi zat warna dari kulit buah manggis menggunakan kromatografi lapis tipis. Kromatografi ini menggunakan fase diam selulosa dan fase gerak BAA (butanol-asam asetat-air), $\mathrm{BuHCl}$ (butanol-HCl), dan Larutan $\mathrm{HCl} 1 \%$. Hasil analisis kromatografi ini menunjukkan adanya noda berwarna 
merah, ungu dan noda berwarna coklat (Gambar 3). Berdasarkan analisis menggunakan spektrofotometer, panjang gelombang maksimal untuk zat warna yang di ekstrak dari kulit buah rambutan ini pada 520nm, maka noda yang dianggap pewarna utama adalah noda yang berwarna merah ungu.

Nilai Rf zat warna yang ada pada kulit buah manggis ini paling mendekati antosianin monoglikosida Pelargonidin 3glukosida seperti yang ditemukan dalam daun bunga Aster Cina (Harborne, 1996). Noda 1 (warna merah ungu) mendekati antosianin standar tersebut untuk fase gerak $\mathrm{BuHCl}$ dan $\mathrm{HCl} 1 \%$. Sedangkan untuk BAA berbeda. Hal ini disebabkan kemungkinan adanya zat warna lain dalam kulit buah manggis yang dipengaruhi oleh varietasnya.

\section{KESIMPULAN}

1. Pelarut yang paling optimal untuk ekstraksi zat warna dari kulit buah manggis adalah etanol.

2. Konsentrasi etanol yang paling optimal untuk ekstraksi zat warna dari kulit buah manggis adalah $70 \%$.

3. Zat warna yang terdapat pada kulit buah manggis diduga golongan antosianin jenis Pelargonidin 3glukosida.

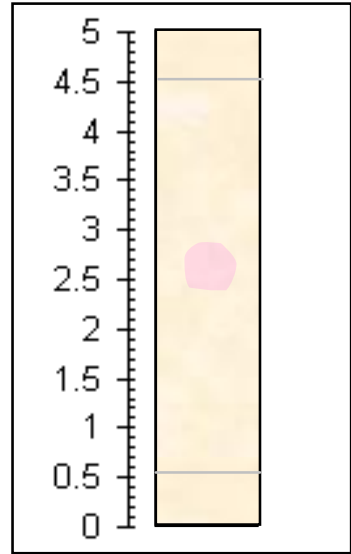

a

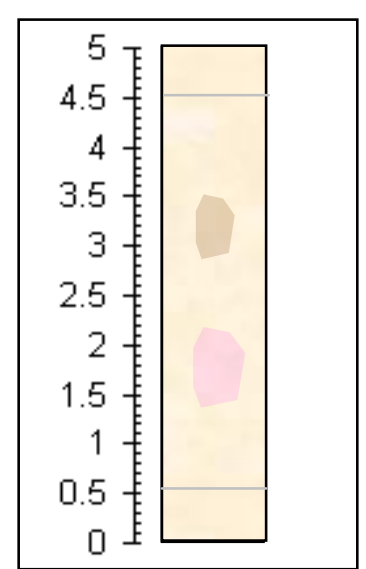

b

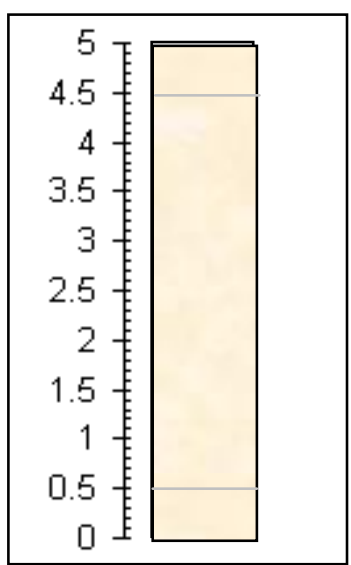

c

Gambar 3. Hasil identifikasi zat warna kulit manggis dengan kromatografi kertas, menggunakan larutan pengembang $\mathrm{BAA}(\mathrm{a}), \mathrm{BuHCl}(\mathrm{b})$, dan $\mathrm{HCl} 1 \%$ (c), dengan Nilai Rf (x 100) masing-masing noda 1 (a) 54, noda 1 (b) 32, noda 2 (b) 68, noda 1 (c) 14, dan noda 2 (c) 33 .

\section{DAFTAR PUSTAKA}

Bao, B., and Chang, K.C. 1994. Carrot Juice, Carotenoids, and Nonstarchy Polysaccharides as Affecte by Processing Condition. Journal of Food Science 59 (6) : $1155-1158$.

Budiarto, H. 1991. Stabilitas Antosianin (Garcina mangostana)dalam Minuman Berkarbonat.(Skripsi).
Jurusan Teknologi Pertanian. Institut Pertanian Bogor. Bogor.

Dirjen Tanaman Pangan Holtikultura. 2004. Pedoman Produksi Manggis.

online

www.fintrac.com/indoag/prodqui $\mathrm{d} /$ manggis.htmL.

Hanum, T. 2000. Ekstraksi dan Stabilisasi Zat Pewarna Alam dari 
Katul Beras Ketan Hitam (Oryza sativa glutinosa). Buletin Teknologi dan Industri Pangan XI (1) : $17-23$.

Harborne,J.B. 1996.Metode Fitokimia: Penuntun Cara Modern Menganalisis Tumbuhan. Terbitan kedua. Penerbir ITB. Bandung.

Jenie, B.S.L., Helianti, dan S. Fardiaz. 1994. Pemanfaatan Ampas Tahu, Onggok, dan Dedak untuk Produksi Pigmen Merah olehMonascus purpureus. Buletin Teknologi dan Industri Pangan (5) : $22-29$.

Lee, H.S. and Wicker, L. 1991. Anthocyanin Pigments in the skin of Lychee Fruit. Journal of Food Science 56 (2) : 466 - 483.

Naimah S, dan Lina H. 2004. Pengaruh Konsentrasi Asam dan Waktu Ekstraksi Antosianin dari Kulit Buah Manggis (Garcia mengostana L.). Buletin Penelitian Volume 26 No 1.

Rahayu, R.D. 1989. Mempelajari Ekstraksi Zat Warna Bunga Kembang Sepatu (Hisiscus rosa - sinesis). Prosiding Seminar Tanaman Hias.

Reza, M, Wijaya dan Tuherkih, E. 1994. Pembibitan dan Pembudidayaan Manggis. Penebar Swadaya. Jakarta.

Rismunandar. 1986.Mengenal Tanaman Buah-buahan. CV. Sinar Baru Bandung.

Rukmana, R. 1995. Budidaya Manggis .Kanisius. Yogyakarta.

Shi, Z., Lin, M. And Francis, F.J., 1992. Stability of Anthocyanins from Tradessania pallida. Journal of Food Science 57 (3) :758 - 760.

Wijaya, L.S, Simon B.W. dan Tri S. 2001. Ekstraksi dan Karakterisasi Pigmen dari Kulit Buah Rambutan (Nephelium lappaceum) var. Binjai. Laporan Hasil Penelitian. UNIBRAW, Malang.

Williams, M and Hrazdina, G. 1979. Anthocyanin as Food Colorants : Effect of $\mathrm{pH}$ on the Formationof Anthocyanin-Rutin Complexes. Journal of Food Science 44 (1) : $66-68$. 